\title{
Improving of the heat supply energy efficiency in Russian cities through the individual heat points introduction
}

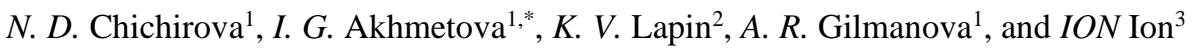 \\ ${ }^{1}$ Kazan State Power Engineering University, Kazan, Russia \\ 2 JSC "Tatenergo", Kazan, Russia \\ 3 "Dunărea de Jos" University of Galaţi, Romania
}

\begin{abstract}
This article states the problems with the use of central heating stations, as well as the need to introduce individual heat points. As a result, the authors considered the issue of improving the energy efficiency of heat supply systems in Russian cities while replacing central heating stations with individual heat points. The beneficial effects of the activities are especially noted.
\end{abstract}

\section{Introduction}

The Russian Federation Energy Ministry each year compiles the All-Russian Energy Efficiency Rating of the Russian Federation subjects. The only possibility for the federation subject to get on this list is the implementation of a whole set of activities to energy efficiency improve, such as, for example, the heat supply systems modernization. This modernization basis is the individual heat points (IHP) introduction with weather and hourly regulation in Russia apartment buildings. This leads to the fuel reduction for heat supply and the transport losses reduction; providing a comfortable temperature in homes, as IHP allows to regulate the heat flow depending on weather conditions; no heat loss, as the water heats up directly in the house itself. The modernization aim is the substantial savings of the heat carrier and cash for thermal energy consumers. As a result, consumers will receive higher quality and reliability services, and energy companies will work with the another level infrastructure.

\section{The need for the individual heat points introduction}

The need to replace central heating units with individual ones is very high. Scientists note that the excess in the consumption of thermal energy for heating needs on average across Russia is $19.8 \%$, and the excess in thermal energy consumption for hot water supply needs is equal to $12.1 \%$. [1]

So, in Russia, the automated individual heat points using is gaining serious proportions. This was influenced, initially, by the introduction in 1996 of Federal Law No. 28 “On Energy Saving” [2], in 2009 its updated version - Federal Law No. 261 "On Energy Saving and Improving Energy Efficiency" [3], and, consequently, changing in 2012, the technological requirements for centralized heat supply "Heating, ventilation, air conditioning. [4]

As for the equipment cost, it is known that the transfer of buildings from central heating station to heat supply using IHP reduces the total cost. This happens despite the large total cost of IHP equipment in several buildings as compared to the equipment of a single central heating station. The reason is that there is no need for intra hot water networks - no need to pay for their transfer during the water heaters transfer to the IHP. [5], [6], [7].

\section{Heat supply system problems when using a central heating station}

In the current situation in the heating industry as a whole, barrier to the transition to a new level of energy efficiency in the housing and utilities system may be due to a number of factors:

- the absence of interested parties who are ready to invest money in the modernization of the existing centralized hot water system, as the mechanism for invested funds returning is not provided by law;

- lack of incentive for resource-supplying organizations due to the lack of tariff sources for such activities funding.

Centralized hot water supply to consumers from central heating stations owned by heat supply organizations has always been considered as an integral part of the heat supply process. Heating of cold tap water in the central heat supply stations was not legally regulated as a commodity production until December 2011. With the adoption of the Federal Law of 07.12.2011 No. 416 "On Water Supply and Wastewater Disposal" [8], the centralized hot water supply in closed systems (from the central heating point) was governed by this law, and in open ones - by Federal Law of July 27, 2010 No. 190- Federal Law "On Heat Supply" [9].

*Corresponding author: irina_akhmetova@mail.ru 
This innovation has led to the many problems appearance in all areas of heat supply organizations activity, as a rule, which also provide hot water:

- organizational, including the appearance of two types of contracts (heat supply and hot water supply) with the problem of heat supply distribution between them according to the regulatory method;

- investment, associated with some objects assignment of simultaneously to heat supply and hot water supply systems;

- tariff, including a complex and incomprehensible to consumers' methodology for thermal energy and hot water calculating tariffs, namely, cross-subsidization between consumers with different heat-consuming equipment.

Thus, a situation arises when a consumer who does not have a connection to the central heating station due to the presence of an individual hot water heater in the heating station of the object pays for the hot water equipment maintenance and networks related to other consumers in the hot water tariff. An obstacle to the tariff differentiation according to the connection scheme for the tariff setting regulator is the factor of the citizens' maximum payment exceeding. This is an incentive for self-installation of IHP by the owners.

At the same time, due to the increased wear of the central heating station equipment (primarily deaeration and water treatment systems) and hot water supply networks, which has a systemic nature in the heat supply industry, the main problem of centralized hot water supply is the need to maintain the hot water quality. Increased wear of centralized hot water networks is primarily due to the oxygen presence in the hot drinking water, as a factor in aggressive corrosion of the pipeline flow. As a consequence, the service life of hot water networks does not exceed 7 years with a regulatory period of 20 years.

The hot water quality is established by Sanitary rules and Regulations 2.1.4.2496-09. [10] These sanitary and epidemiological rules and regulations establish hygienic requirements for water quality and the centralized hot water systems organization, as well as rules for water quality monitoring. According to the specified Sanitary rules and Regulations during operation of centralized hot water supply systems, the temperature in the water intake points should not be below $+60^{\circ} \mathrm{C}$, the static pressure should not be less than $0.05 \mathrm{MPa}$ with filled pipelines and water heaters with tap water.

Thus, the need to solve the problem of hot water quality comes to the forefront of urban engineering systems development with hot water consumers.

Due to the lack of tariff sources for upgrading equipment and centralized hot water networks, the main energy-efficient solution is to transfer the function of hot water production from the heat supply organization to the capital construction object of consumers by IHP installing with independent hot water production.

Each IHP includes a hot water module with a plate heat exchanger, which is installed directly in the designated place of a residential house, which will allow to make the transition from a four-pipe to a two-pipe heating system and eliminate the central heating station.
At the same time there is no need for the central heating point maintenance and the hot water networks.

In addition to addressing the issue of hot water quality during the IHP installation, consumers have the effect of heat energy losses reducing during decommissioning of the central heating station and hot water networks. The effects that are not accounted for include the reduction of hot water networks disconnection periods at consumer facilities as a result of hot water networks breakthroughs and during their planned repair, the repair work elimination on hot water networks in the areas adjacent to the facilities.

\section{Solving the hot water supply problem in cities in Russia}

In the Moscow region, as part of the work carried out jointly with the Russian Federation Energy Ministry, a large-scale project was implemented to install 118 IHPs at the most complex facilities - municipal kindergartens and schools. In the first stage, implemented in 2014, 77 IHPs were installed at public sector facilities, in close cooperation with local authorities. In 2015, another 41 IHPs were installed. [11]

During the working period, the all boiler houses modernization was carried out in the Mytishchi municipal area, a significant part of the heating networks was replaced using modern technologies, 84 IHPs were installed in schools and kindergartens, which accounted for more than $90 \%$ of such social sphere facilities. In 2014, at the expense of subsidies allocated to the Moscow region as part of the federal energy efficiency program, 8 IHPs were installed at the public sector facilities of the city. As a result of the reconstruction, 50 central heating stations (CHS) and $150 \mathrm{~km}$ of hot water supply networks were decommissioned, the losses in heat networks were reduced from $31 \%$ to $8.7 \%$. [12]

Since 2007, the program "Modernization of district heating systems" has been launched in Ufa, 414 IHPs have been installed during the course of the European Bank for Reconstruction and Development program, 35 IHPs were commissioned in 2008, 325 IHPs in 2009, and 54 IHPs in 2010. As a result of this program implementation, the heat consumption savings amounted to about $8 \%$, and the hot water saving, respectively, about $12 \%$. The project has a direct impact on the heat supply services quality improving for approximately 50,000 families in the city. [13]

In Gorno-Altaisk, in accordance with the Energy Efficient City program, 46 IHPs were installed and commissioned. [14]

In the city of Kaliningrad, a similar project was carried out according a program provided by the European Bank for Reconstruction and Development. Within the project, 126 IHPs were installed. The experience of IHP installation and operation allowed to reduce the construction volume of the heat point room, reduce the pipelines length by 2 times due to the 4-pipe heating system failure, capital costs reduce for equipment maintenance and heat-insulating materials by $20-25 \%$, consumption electricity reduce compared to the 
energy-intensive equipment of the central heating point, to optimize the energy metering system. IHP is fully automated, which reduced operating costs by $40-50 \%$. Due to the use of the automatic control system, the thermal energy consumption at the facilities, according to the results of the 2012-2013 heating season, decreased by $30 \%$. The time required for the heat points installation has been reduced by 4-5 times due to the use of prefab assembly units. [15] According to preliminary estimates, the economic efficiency of the IHPs use of ranged from 10 to $25 \%$, with the equipment payback period ranging from 1 to 2.4 years.

In the city of Kazan, the depreciation state of the centralized system was estimated at $65 \%$ :

- Trunk networks - 32\%;

- Quarterly heating network - 75\%;

- Quarterly hot water network - 66\%;

- Equipment and buildings depreciation - 80\%.

If it were decided to restore and repair the existing equipment and buildings of the central heating station and the quarterly hot water networks (in 2016 prices), the costs would have amounted to 3.8 billion rubles, including:

- bringing the equipment and buildings of the central heating station in a standard condition - 1.6 billion rubles (replacement of existing heat exchangers with modern efficient small-size collapsible plates; replacement of cooking processes automation; replacement of pumping equipment, reconstruction of buildings);

- reconstruction of hot water supply networks from the central heating point to consumers -2.2 billion rubles (replacement of hot water supply networks with modern polymer pipelines).

In the city of Kazan in 2012, IHP was installed at consumers in the amount of 29 pieces, 7 CHSs were liquidated. The project was implemented under a joint financing program at the expense of the budget (energy saving program) and own funds of Kazan Thermal Network Company. The volume of investments in the project amounted to 18 million rubles, including the share of "Kazan Thermal Network Company" - 10 million rubles. When deciding on the implementation of a pilot project for the consumers transfer to the IHP, the selection of objects was carried out primarily from improving the quality and reliability of hot water supply due to constant customer complaints. The most problematic objects with no circulation lines and the most distant from the central heating station, the most degree of the hot water networks deterioration, the high level of heat loss on the above-mentioned networks were selected. The project implementation has reduced the amount of heat consumption for the hot water supply needs by an average of $26 \%$.

In 2015 , based on the positive experience of the pilot project implementation, JSC “Tatenergo" implemented the first stage of the IHP transition program with the water heating functions for the hot water supply needs and subsequent central heating stations liquidation in Kazan:

- 271 IHPs were mounted;

- 22 CHSs were liquidated;
- the volume of investments amounted to 126 million rubles.

The second stage of the IHP program transition with the functions of water heating for the hot water supply needs and the subsequent elimination of the central heating station in Kazan is to install the IHP modules at 1,378 consumer facilities.

Investments amounted to 1.2 billion rubles. The sources of funds are the budgets of the Tatarstan Republic, the city of Kazan. The period of the IHP installation is 2017/2018. As a result of the implementation of the IHP installation program in 2018, heat loss in the networks of JSC Tatenergo is decreased by 40 thousand Gcal of heat or by $4.4 \%$ in relative terms.

In the city of Naberezhnye Chelny, the program of energy saving and energy efficiency for 2010-2014 provides for hot water networks transfer systems from open to closed by installing heaters and regulators at the expense of the following financing sources:

- in social and cultural institutions - the budget of the Russian Federation is $10 \%$, the budget of the Republic of Tatarstan (RT) is $30 \%$, the budget of the city is $60 \%$;

- in apartment buildings - the budget of the Russian Federation is $10 \%$, the budget of the RT is $30 \%$, the budget of the city is $30 \%$, extra-budgetary funds are $30 \%$.

Performed activities:

- to improve the hot water supply quality;

- to reduce the consumption of thermal energy by the population by $27 \%$;

- to reduce the cost of the coolant transferring;

- to free up reserves of thermal networks capacity for new consumers connecting.

\section{Conclusion}

The World Bank annually presents a rating of countries on the government measures for sustainable energy implementation (Regulatory Indicators for Sustainable Energy). One of the sections is an energy efficiency rating. The Russian Federation is in the middle group by results and ranks 46th out of 133 countries. [16] The lag of the Russian Federation is traced; it impedes the achievement of target indicators, including the GDP energy intensity.

Therefore, it is necessary to introduce key energysaving and energy-efficient technologies. In this case individual heat points with automatic hour and weather control.

The highest rates of IHP implementation with automatic weather control in public sector buildings are observed in the federal city of St. Petersburg (20\%), the Republic of Tatarstan (14\%), Lipetsk (12\%) and Murmansk (12\%) regions. The average value of the indicator in Russia is $5.4 \%$.

The share of apartment buildings equipped with IHPs with automatic regulation of the coolant temperature averages across Russia at $4 \%$. The leaders are the following subjects: Samara region (27\%), Republic of Altai (17\%), Belgorod region (17\%), Khanty-Mansiysk Autonomous Okrug - Ugra (13\%). [17] 
The annual expected effect from the installation of IHP with metering and automatic control units can be up to $22 \%$ of the consumed thermal energy. [18] The average payback period of projects is from 1 to 5 years, so it can be concluded that the economic efficiency of implementing IHP in the Russian Federation constituent entities is quite high

\section{References}

[1] S. Glukhov, M. Lebedev, Investigation of the degree of efficiency of automatic control in heating systems News of Transsib 2, 64-70 (2010)

[2] Federal Law "On Energy Saving" 28, URL: http://www.consultant.ru/document/cons_doc_LAW_99 06/ (1996)

[3] Federal Law "On Energy Saving and Improving Energy Efficiency and On Amending Certain Legislative Acts of the Russian Federation" 11.23.2009 N261,

URL: http://www.consultant.ru/document/cons_doc_LAW_93 978/

[4] SP 60.13330.2016 Heating, ventilation and air conditioning, 6.1.2, Updated edition SNiP 41-012003, URL: http://docs.cntd.ru/document/456054205

[5] V. Livchak, Consistency in fulfilling the requirements of improving the energy efficiency of apartment buildings Energy saving 6, 14-22 (2010)

[6] V. Livchak, Installing IHP in buildings instead of replacing worn-out equipment in the central heating point and re-routing the hot water supply network Energy Saving 1, 36-40 (2008)

[7] V. Livchak, Automation of heat supply and metering control AVOK 4, 44-51 (1998)

[8] Federal Law of 07.12.2011 416, "On Water Supply and Wastewater Disposal". URL: http://www.consultant.ru/document/cons_doc_LAW_12 $2867 /$

[9] Federal Law dated July 27, 190 "On Heat Supply". URL: http://www.consultant.ru/document/cons_doc_LAW_10 2975/ (2010)

[10] Resolution of the Chief State Sanitary Doctor of the Russian Federation of April 7, 20, "On approval of SanPiN 2.1.4.2496-09" URL: http://base.garant.ru/12167072/ (2009)

[11] Improving the energy efficiency of municipal infrastructure systems in the Moscow region Moscow Regional Duma.

[12] V. Fazin, Implementation of the largest heat supply modernization project in Russia 03.27.2015 URL: http://energoeffekt.info/heat/articles/15618-v-

podmoskove-realizuetsya-krupneyshiy-dlya-rossiiproekt-po-modernizacii

[13] Introduction of innovative developments in the housing and utilities sector Ufa, Russia URL: http://mag.e-gorod.ru/lib/12003/ (2015)

[14] Thanks to energy saving measures in the Altai Republic, more than $20 \%$ of heat energy was saved Center for energy saving automation URL: http://caesber.ru/news/energo/35970/
[15] A. Gusev, The results of the project for the installation of individual heat points in apartment buildings Heat Supply News 8(156), 48-49 (2013)

[16] Policy Matters : Regulatory Indicators for Sustainable Energy (RISE) 2018 World Bank Group 86 URL:

http://documents.worldbank.org/curated/en/5530715442 06394642/Policy-Matters-Regulatory-Indicators-forSustainable-Energy

[17] State report on the state of energy conservation and energy efficiency in the Russian Federation, Ministry of Economic Development, 2018, Moscow,

URL: http://economy.gov.ru/minec/about/structure/depgostarif/ 201812103 (2017)

[18] Y. Zvonareva, Y. Vankov, S. Nazarychev, Evaluation of the economic effect for consumers when installing automated metering and regulation of heat energy, Engineering Bulletin of the Don, 38, 4-1 98 (2015) 